\title{
PEMBELAJARAN MUSIK BERBASIS SISWA DENGAN PENDEKATAN LOCAL GENIUS
}

\author{
Oleh \\ Imam Ghozali ${ }^{1}$
}

\begin{abstract}
Abstrak : Musik merupakan media komunikasi yang dapat digunakan untuk menyampaikan eksistensi individu melalui ekspresi suara, yang dapat diapresiasi individu. Pengembangan musik melalui pembelajaran musik di sekolah perlu memasukan unsur nilai-nilai musik tradisi, yang dapat dilakukan sejak dini.

Belajar musik seperti halnya belajar bahasa, dengan tahapan-tahapan mendengar, meniru, memikirkan, mengaplikasikan, dan memanfaatkan. Pembelajaran musik perlu memperhatikan unsur-unsur seperti potensi dasar, metode, aktivitas, dan alur yang tepat, yang dapat dilakukan dengan prinsip pembelajaran musik berbasis siswa. Pembelajaran tersebut menekankan pada prinsip: sesuai potensi siswa, memperhatikan budaya daerah setempat, mulai dari yang sederhana, menggunakan lagu yang sesuai, instrumen musik sesuai yang ada, praktek ansambel, dan menampilkan hasil kreasi.
\end{abstract}

Kata Kunci : Bahasa musik, Musik tradisi, Ansambel musik. Local genius.

\section{Pendahuluan}

Musik adalah alat komunikasi manusia yang unik, dengan aransemen suara yang terstruktur sangat baik seperti susunan dalam tata bahasa. Mendengarkan musik dapat diibaratkan seperti seseorang yang mendengarkan orang lain berbicara dengan bahasa yang tidak ia pahami, namun ia bisa mengerti dengan interpretasinya, melalui nada bicaranya, tinggi-rendah, keras-lembut, dan sebagainya. Musik bisa didengarkan dan dinikmati baik oleh orang yang memiliki pengetahuan tentang musik ataupun yang awam sama sekali tentang musik. Karena musik dapat

${ }^{1}$ Imam Ghozali : dosen Prodi Seni dan Musik Jur. PBS FKIP Untan 
dinikmati melalui elemen-elemen seperti, dinamik, register (wilayah nada), model (bentuk aransemen), tempo, artikulasi, dan sebagainya, dan itu sifatnya sangat individual.

Baik disadari maupun tidak, musik merupakan suatu hal yang diperlukan kehadirannya atau bahkan kehadirannya menjadi suatu keharusan, apapun bentuknya. Seperti halnya juga bahasa, musik dapat juga digunakan sebagai alat komunikasi antar maupun inter individu. Musik bisa menjadi alat untuk menyampaikan eksistensi individu melalui ekspresi suara yang dapat diapresiasi oleh individu lain. Musik juga bisa mengisi relung-relung kosong dalam jiwa, sehingga mampu menghadirkan suatu nuansa atau pengalaman yang baru melalui wujud keindahan maupun hadirnya kedamaian dan kepuasaan.

Melalui perannya, musik menjadi bagian tak terpisahkan dari kehidupan manusia, baik secara individu maupun kelompok. Musik menjadi salah satu sisi budaya manusia. Dengan demikian musik dapat memberikan gambaran karakter masyarakat yang memeliharanya, yang terwujud dalam tatanan musik-musik tradisi. Hal demikian sekaligus menjadi ciri local genius masyarakat tertentu, dimana musik tradisi tersebut hidup dan berkembang.

\section{Musik Indonesia}

Ki Hajar Dewantara (1962: 314) mengatakan: "Mantan Presiden Filipina Quezon pernah mengatakan bahwa, Bangsa Filipina sudah berdiri sebagai rakyat merdeka. Tetapi kultur yang asli sudah lenyap dan berganti dengan budaya Spanyol dan Amerika. Bangsa Filipina sebagai bangsa merdeka yang tidak mempunyai pakaian kebangsaan sendiri. Bersyukur, bangsa Indonesia tidak mengalami hal serupa dengan Filipina. Indonesia sangat kaya dengan ragam kebudayaannya, yang masih terpelihara di masingmasing daerah.

Musik sebagai salah satu unsur budaya, juga memberikan identitas tersendiri bagi suatu bangsa. Musik Indonesia adalah musik yang mempunyai akar tradisi daerah yang tersebar di seluruh wilayah Indonesia. Selain itu termasuk juga musik-musik yang telah diadopsi dan beradaptasi dalam kurun 
waktu yang cukup lama, sehingga tumbuh dan berkembang sesuai dengan karakter dan kepribadian bangsa Indonesia. Termasuk dalam dua kategori di atas, yang pertama adalah musik - musik tradisional dari berbagai daerah seperti musik gamelan, angklung, tarling, talempong, calung, sapek, dan sebagainya. Kemudian yang kedua, merupakan musik yang berasal dari luar namun telah menjadi bagian dari tardisi masyarakat di Indonesia, seperti musik keroncong, melayu/dangdut, tanjidor, dan sebagainya.

Prof. Dr. R.M. Soedarsono dalam bukunya mengatakan bahwa tangga nada diatonis yang berasal dari Barat bukan saja menghadirkan perpaduan musik Timur dan musik Barat, namun justru tangga nada ini yang mendasari terciptanya musik nasional Indonesia (2003: 61). Pendapat tersebut seperti mengesampingkan musik tradisional sebagai bagian dari musik Indonesia. Namun jika dikaji dari konteksnya bahwa hal tersebut terjadi pada masa perjuangan, yang lebih menonjolkan persatuan sehingga seperti mengesampingkan unsur musik tradisionalnya. Disamping itu, pendapat tersebut hanya mengarah pada proses munculnya lagu kebangsaan dan lagu-lagu perjuangan, sehingga bukan berlaku untuk pengertian musik Indonesia secara luas.

Jadi pada dasarnya musik Indonesia adalah musik yang lahir di daerah-daerah di seluruh wilayah negara Indonesia yang masih terpelihara, baik yang masih orisinil maupun yang telah mengalami transformasi. Termasuk dalam pengertian ini adalah musik dari luar yang telah diserap dan disesuaikan dengan tradisi bangsa Indonesia, sehingga telah menjadi bagian dalam kehidupan masyarakat Indonesia. Dengan pengertian ini maka musik Indonesia tidak bersifat statis dan mati, namun masih terus dan akan terus mengalami perkembangan sesuai dengan berkembangnya masyarakat.

\section{Kondisi Musik di Indonesia}

Musik di Indonesia dilihat dari beberapa indikator, seperti ajang lomba dari menyanyi solo hingga group musik, dari anak-anak hingga dewasa, banyaknya industri rekaman, menjamurnya studio musik rental, menunjukkan grafik perkembangan yang positif. Perkembangan musik di 
Indonesia yang cukup signifikan adalah dengan lahirnya musik pop Indonesia pada tahun 1950-an hingga tahun 1960-an, yang dipengaruhi oleh musik pop Amerika Serikat dan juga Amerika Latin (Soedarsono, 2003: 269). Perkembangan dari era 50-an hingga sekarang telah melahirkan tokoh-tokoh musik yang cukup melegenda dengan masing-masing alirannya seperti Titik Puspa, Jack Lesmana, Rhoma Irama, Iwan Fals, dan group yang legendaris Koes Plus dan lain-lain.

Namun perkembangan musik di Indonesia tidak serta merta diikuti dengan perkembangan musik tradisi Indonesia. Bahkan mungkin dapat dikatakan seperti perbandingan dalam matematika, deret kali dan deret hitung. Musik tradisi mulai kehilangan tempat baik di hati maupun di pentas masyarakat, sebagai akibat dari gelombang globalisasi musik, yang merambah hingga ke kampung-kampung. Musik tradisi yang kurang kuat fondasinya di masyarakat mulai tergerus, hingga sangat berpotensi ambruk.

Beruntung dalam kondisi yang demikian bermunculan dewa-dewa kreatif yang menciptakan pemecah gelombang, dengan mengkawinkan keanggunan musik tradisi dengan kekuatan fleksibilitas musik diatonis Barat. Manthous telah meracik gamelan Jawa dengan alat-alat musik diatonis, hingga menghasilkan musik campursari yang telah dapat diterima berbagai kalangan. Ki Manteb Sudarsono yang juga telah memasukan alat-alat musik diatonis dalam musik pengiring wayangnya, bahkan sekarang sudah banyak dalang yang menyisipkan penyanyi pop/dangdut dalam pergelaran wayangnya. Daeng Sutigna yang telah membuat alat musik angklung dalam tangga nada diatonis, sehingga mempunyai fleksibilatas dalam tonalitas, hingga mudah dipahami dan dikembangkan hingga di mancanegara. Mang Ujo dengan saung angklungnya, dan sederetan nama yang lain yang sangat berperan penting dalam usahanya mengembangkan musik tradisi, hingga diterima berbagai lapisan masyarakat.

Dari usaha kreatif para seniman tradisi, kini marak musik-musik tradisi dalam kemasan baru seperti campursari, cong-dut (keroncong dangdut), bang-dut (bangreng dangdut), musik jaipong, dan sebagainya. Musik-musik tadi mampu bersanding dengan karya musik lain baik dalam 
pementasan di masyarakat maupun dalam kemasan video compact disk (vcd) dan kaset, hingga penyebaran melalui dunia maya.

Namun perkembangan yang positif ini jika tidak dibarengi dengan pemberian fondasi budaya yang kuat, kemungkinan juga akan tergerus dengan budaya musik yang baru, yang pada gilirannya juga tetap akan berhadapan dengan kepunahan. Sehingga sangat mungkin akan mengalami seperti yang pernah dialami Filipina. Musik tradisi sebagai jati diri bangsa perlu diperkenalkan sejak dini kepada anak-anak terutama melalui berbagai jalur pendidikan, sehingga anak sejak kecil tidak merasa asing dengan budaya sendiri. Anak-anak tidak mentertawakan tatkala diperdengarkan musik tradisi, karena merasa asing dan menganggap sesuatu yang aneh. Musik tradisi sebagai nilai perlu dimiliki oleh anak-anak Indonesia, untuk menjadi fondasi sebelum bangunan musik yang lain didirikan di atasnya.

\section{Pembelajaran Musik, Peran dan Masalahnya}

Seni mengandung potensi tertentu yang dapat difungsikan untuk membantu pendidikan (Soehardjo, 2005: 165). Musik sebagai salah satu bidang seni mempunyai peran sangat besar dalam dunia pendidikan, karena dapat menjadi salah satu media untuk mencapai tujuan pendidikan. Menurut Soehardjo, ada dua kemungkinan kemampuan yang dihasilkan oleh peserta didik dalam melakukan kegiatan seni. Pertama kemampuan melakukan kegiatan seni, kapabel menggunakan modus imitasi dan atau modus ekspresi, kedua adalah, kemampuan lain sebagai dampak dari proses pembimbingan, pengajaran dan atau pelatihan tersebut ((2005: 2). Kedua adalah merupakan kapabilitas non-seni seperti, menghargai buah pikiran atau karya orang lain. Hal tersebut berkait erat dengan pembentukan sikap dan perilaku positif, sesuai dengan tujuan pendidikan yaitu membentuk pribadi yang utuh dan unggul.

Musik merupakan salah satu cabang seni yang mempunyai fungsi melatih kepekaan dan keterampilan, melalui media suara. Unsur-unsur musik terdiri dari 1) unsur utama, yaitu irama, melodi, harmoni, dan bentuk lagu, 2) unsurunsur ekspresi, yaitu tempo, dinamik, dan warna nada (Jamalus, 1998: 7). 
Secara sederhana musik terdiri atas melodi dan pengiringnya. Untuk menulis sebuah melodi digunakan lambang musik yang diantaranya disebut dengan not.

Namun pembelajaran seni musik khususnya di sekolah-sekolah, baik sekolah dasar maupun lanjutan, seringkali kurang memperhatikan terutama dari segi modus ekspresi. Pembelajaran seni musik malah sering menjadi beban tambahan bagi siswa. Mereka dijejali dengan teori-teori musik yang kadang-kadang juga kurang dipahami oleh gurunya. Hal ini sering diperparah dengan sikap guru yang menjadikan teori musik menjadi sesuatu yang sulit bagi siswanya, untuk menutupi kekurangpahamannya terhadap teori yang diajarkannya. Demikian juga dengan sikap guru yang menerapkan ketentuan yang berat bagi siswa yang ingin praktek bermusik, demi menutupi kelemahan guru bersangkutan dalam penguasaan instrumen musik. Hal demikian perlu segera adanya 'penyadaran' melalui berbagai terobosan agar hal-hal berkait dengan ketidaktercapaian hakekat dari tujuan pembelajaran seni tidak berkelanjutan.

Pada akhirnya siswa sebagai subyek didik, harus menanggung kerugian yang tidak dirasakan secara langsung pada saat itu. Fenomena yang kita rasakan sekarang seperti kekerasan, keberingasan, ketidakpedulian, rendahnya toleransi, ketidakjujuran dan sejenisnya, bisa sangat 'dimungkinkan' sebagai dampak dari 'tidak beresnya' pembelajaran dalam bidang seni.

\section{Konsep Pembelajaran Musik}

Banyak para ahli yang telah menawarkan konsep tentang pembelajaran musik dengan teori yang mereka kemukakan. Salah seorang yang mengemukakan teori tentang pembelajaran musik adalah Edwin E. Gordon, seorang pengajar, peneliti, dan editor dari Amerika Serikat. Prinsip dasar yang harus diperhatikan dalam pembelajaran musik menurut Gordon adalah sebagai berikut:

1. Audiation 
Mendengar dan menyerap bunyi musik adalah hal yang utama dalam belajar musik. Untuk itu diperlukan pengetahuan dasar guna membangun kemampuan seseorang memaknai musik. Karena audiation bukan hanya sebatas mendengar musik, namun lebih kepada proses kognitif dalam menerima dan memberikan makna bunyi musik.

2. Music Aptitude

Potensi dasar (talenta) musikal seseorang biasanya berbeda satu dengan yang lain. Jika hal ini dipahami dan bisa diketahui oleh pendidik adanya kemampuan dasar yang berbeda, akan sangat membantu siswa mengembangkan potensi musiknya.

3. Methodology

Dalam pembelajaran musik, metode yang tepat akan sangat mempengaruhi cepat/ tidaknya keberhasilan sebuah proses belajar.

4. Learning Squence Activities

Dalam kegiatan ini siswa belajar untuk mendengarkan nada dan pola ritme, untuk membangun/mengisi kepekaan musik.

5. Classroom Activities

Aktivitas musik di dalam kelas dengan bimbingan guru akan sangat penting, karena memberikan pengalaman bermusik bagi siswa.

6. Early Childhood

Pembelajaran musik pada usia dini akan lebih membantu membentuk fondasi yang kuat pada anak.

7. Specific Application to Music Instruction

Metode, teknik, dan materi dalam pelaksanaan pembelajaran musik perlu sangat variatif dalam pengajarannya.

8. Types and Stages of Audiation

Terdapat jenis-jenis dan tahapan-tahapan audiasi dalam pembelajaran musik.

Dalam metode pembelajaran musik, Gordon membuat sebuah konsep berupa tahapan-tahapan yang identik dengan proses belajar bahasa pada bayi, sebagai berikut:

- Dimulai dengan proses mendengarkan

- Menirukan/mengimitasi dari apa yang didengar

- Mulai berpikir tentang apa yang ia tirukan 
- Mencoba berimprovisasi dengan merangkai hal yang telah ada/terekam

- Mencoba mengkomunikasikan apa yang telah didapat

- Tahapan terakhir adalah mengembangkan pola pikir dalam rangka mengaplikasikan apa yang telah didapat untuk berkomunikasi

\section{Pembelajaran Musik, Dari, Oleh dan Untuk Siswa (Pembelajaran Musik Bebasis Siswa)}

Sejak kapan dan bagaimana sejarah musik dimulai secara pasti tidak ada yang tahu. Barangkali sejalan dengan sejarah dan perkembangan manusia melalui aktivitas sehari-harinya. Yang jelas sekarang musik dapat didengarkan dimana-mana, sangat akrab dengan aktivitas keseharian kita. Maka menjadi sangat ironis jika musik yang sangat akrab dengan kita dimana tempat dan waktu, menjadi sesuatu yang sulit dalam pembelajarannya di sekolah. Untuk itu diperlukan perhatian khusus, sehingga pembelajaran musik kembali pada tujuan dan porsi semula yang diinginkan. Bahkan bisa bermanfaat seperti yang dikatakan Campbell (2001: 1) bahwa, musik mampu menghibur jiwa. Musik membangkitkan dalam diri kita semangat untuk berdoa, belas kasih, dan kasih sayang. Musik juga menjernihkan pikiran dan telah dikenal membuat kita menjadi lebih cerdas.

Ada beberapa prinsip-prinsip pembelajaran musik yang mungkin berguna untuk diterapkan di sekolah, baik sekolah dengan kemampuan sarana dan potensi musikalitas siswa yang baik, cukup maupun kurang. Hal ini dimungkinkan karena prinsip yang digunakan adalah dengan memperhatikan dan menekan aspek eksplorasi bukan doktrinasi bagi siswa. Prinsip-prinsip tersebut adalah:

\section{Berangkat dari potensi siswa}

Dalam pembelajaran musik sangat perlu dipertimbangkan potensi dasar yang dimiliki siswa. Pembelajaran musik perlu berangkat dari siswa, sehingga bisa menentukan dari mana dan materi apa yang sesuai untuk siswa bersangkutan. Dalam hal ini sangat dimungkinkan perlakuan yang berbeda pada beberapa siswa, terutama bagi siswa yang berotensi lebih maupun siswa 
dengan potensi yang kurang. Pembelajaran lebih memfokuskan pada proses bukan pada hasil.

\section{Memperhatikan budaya setempat}

Lagu sebagai media pembelajaran musik, sangat berperan besar untuk menjadi daya pikat bagi siswa. Penggunaan lagu-lagu daerah setempat dengan bahasa syair yang dimengerti oleh siswa, akan mudah diterima dan dipahami oleh siswa, selain itu juga akan menjaga kelestarian budaya yang ada. Hal ini tentu saja dengan tidak mengabaikan lagu daerah lain, maupun lagu-lagu lain yang banyak digemari dan sudah sangat familier dengan siswa, melalui pertimbangan bijak sang pengajar.

Ada dua pertimbangan penting dalam pendekatan budaya setempat sebagai salah satu faktor penunjang utama dalam keberhasilan pembelajaran musik. Pertama, budaya setempat dalam hal ini adalah lagu-lagu ataupun musik daerah, lahir dan berkembang bersama dengan berkembangnya budaya masyarakat setempat, sehingga isi dari lagu, yang tertuang melalui melodi dan syair menggambarkan perilaku masyarakatnya. Dengan demikian mempelajari lagu daerah setempat berarti juga mempelajari budaya masyarakat setempat yang secara tidak langsung ikut juga melestarikan budaya tersebut. Kedua, karena siswa sebagai subyek didik mempelajari sesuatu yang berkaitan erat dengan diri dan lingkungannya, maka sangat dimungkinkan tidak banyak menemui kendala. Dengan demikian proses pembelajaran bisa lebih cepat, terlihat sederhana, dan menarik.

\section{Dari yang sederhana}

Pengajaran musik perlu dimulai dari hal yang sederhana 'dengan standar siswa', namun tidak di bawah standar rata-rata. Guru lebih berperan sebagai fasilitator, sehingga siswa merasa tidak tertekan dan terbebani. Hal ini penting untuk membangun kesan positif siswa, sehingga tidak mendatangkan 'kesan pertama begitu sulit', namun terciptanya 'kesan pertama begitu menggoda'.

\section{Ciptakan lagu sendiri}

Ini sangat penting dalam sebuah pembelajaran musik di sekolah. Untuk tingkat SD tentu saja memerlukan peran guru yang lebih besar. Bagi 
siswa SD pembelajaran ini akan lebih bisa tepat sasaran, karena tingkat kesulitan lagu, jangkauan suara, dan syair yang dituliskan disesuaikan dengan kondisi dan kebutuhan mereka. Apalagi jika siswa dilibatkan dalam penulisan syair ataupun penyusunan melodi lagu bila memungkinkan.

Untuk tingkat lanjutan bisa dari penciptaan syair lagu hingga sampai pada melodi lagunya. Tentu saja pengajar harus bisa menjadi penuntun yang baik. Dapat menunjukkan aplikasi syair pada melodi dengan tepat, mencarikan berbagai pilihan nada maupun progesive chord-nya. Menuntun setiap langkah hanya diberikan kepada mereka yang benar-benar membutuhkan Sebisa mungkin pengajar tidak menentukan dan memutuskan, namun hanya memberikan pilihan, sehingga siswa betul-betul merasa hasil karya orisinil mereka dan menumpahkan eksperesi mereka lewat karya musik.

Tidak perlu merasa tersaingi jika siswa menghasilkan karya yang mungkin lebih bagus, justru harus merasa bangga, dan perlu diwujudkan dalam bentuk pujian langsung pada siswa bersangkutan. Kendala yang muncul disini mungkin cara menuliskan lagu dalam notasi musik. Namun hal ini bisa diabaikan, yang penting siswa mengerti dengan apa yang mereka tulis melalui lambang-lambang yang mereka pahami, kemudian bisa mengungkapkan lagi lambang-lambang tersebut.

\section{Pengembangan musik melalui praktek ansambel musik}

Rata-rata sekolah di berbagai daerah di Indonesia memiliki kelas 'gemuk', dengan jumlah siswa di atas ideal maksimal, bahkan ada yang mencapai di atas angka 50 dalam satu kelas. Jika dikembangkan praktek musik secara individual akan memakan waktu cukup lama sehingga tidak sankil dan manku. Hal ini akan teratasi dengan mengembangkan pembelajaran musik melalui praktek ansambel musik yang dilandasi dengan kreativitas. Ansambel adalah permainan musik sekelompok orang dengan menggunakan alat musik tertentu. Ansambel bisa dalam bentuk kelompok satu jenis instrumen musik, maupun gabungan dari berbagai jenis alat musik.

Dalam ansambel heterogenitas keterampilan siswa dalam bermusik tidak lagi menjadi masalah berarti. Siswa dapat dikelompokkan sesuai dengan minat dan kemampuannya. Siswa yang terampil dalam kelompok band, siswa yang tergabung dalam paduan suara, siswa yang bisa sedikit 
memainkan pianika, recorder, bahkan siswa yang masih sulit memainkan salah satu alat musik, semuanya dapat berperan. Dalam hal ini yang penting adalah peran pengajar untuk dapat mengaransir lagu sesuai dengan kemampuan keterampilan masing-masing siswa atau kelompok siswa. Ansambel bisa 'mewadahi' semua yang ada baik jumlah maupun kemampuan siswa. Selain dapat melatih keterampilan musik, dapat menumbuhkan saling pengertian, saling menghargai, dan kerja sama, melalui permainan musik bersama.

\section{Instrumen musik = apapun yang bisa dibunyikan}

Sering keterbatasan alat musik yang dimiliki sekolah menjadi kendala dilaksanakannya praktek bermusik. Padahal musik bukan hanya permainan nada, tetapi juga permainan ritmik. Untuk itu, keterbatasan atau bahkan tidak adanya alat musik konvensional di sekolah bukan berarti pembelajaran musik tidak dapat berjalan. Benda-benda seperti galon air, ember, tutup botol, dan sebagainya dapat dijadikan alat musik ritmis. Jika diaransir dengan baik, apalagi digabung dengan alat musik melodis yang ada, akan menjadi 'musik kreatif' yang dapat menghasilkan perpaduan suara yang bisa dinikmati dan mendatangkan kesenangan serta kepuasan di dalam batin.

\section{Pergelaran}

Seorang petinju, pemain bulu tangkis, karatekawan, dan lain-lain, kemungkinan akan merasa sangat jenuh dan kurang semangat jika hanya latihan terus menerus tanpa ada program pertandingan. Demikian juga dengan berlatih musik, siswa akan lebih termotivasi, lebih semangat dan bergairah dalam latihan jika ada program untuk ditampilkan di depan umum melalui sebuah pergelaran. Ada wadah yang bisa memberikan kesempatan kepada mereka untuk menunjukkan eksistensinya. Bagaimanapun manusia membutuhkan pengakuan terhadap eksistensinya. Pergelaran juga dapat berupa penyelenggaraan lomba seperti lomba musik kreatif antar kelas, juga bisa menjadi alternatif lain untuk memberikan dorongan atau rangsangan berkreasi dalam bermusik. 


\section{Pembelajaran Musik Suatu yang Penting dan Dipentingkan Kapan menjadi Suatu Keniscayaan?}

Disadari maupun tidak, musik sangat memberikan efek pada mental dan fisik kita. Sering kita mengalami pengenduran atau bahkan penyaluran emosi melalui musik. Merasakan lebih tenteram, nyaman dan lebih nikmat merasakan sesuatu tatkala ada musik yang dengan sengaja kita dengarkan.

Campbell (2001: 115) mengindikasikan adanya 17 kekuatan musik yang dapat mempengaruhi kerja organisasi tubuh manusia, memberikan efek lahiriah maupun batiniah. Diantara kekuatan tersebut diantaranya, adalah:

- Musik mempengaruhi pernafasan

- Musik mempengaruhi denyut jantung, nadi dan tekanan darah

- Musik mempengaruhi suhu badan

- Musik dapat menaikkan tingkat endorfin

- Musik dapat memperkuat ingatan

- Musik merangsang pencernaan

- Musik dapat mengatur hormon-hormon yang berkaitan dengan stress

Kekuatan musik tersebut tentu saja tidak berlaku sama pada semua jenis musik, namun sesuai dengan karakteristik yang dibentuk oleh unsur-unsur yang terdapat dalam musik tersebut.

Akankah fungsi musik yang sangat bermanfaat dan telah dibuktikan melalui berbagai penelitian tersebut hanya akan menjadi pengetahuan beberapa orang saja? Mungkinkah sesuatu yang tak ternilai ini hanya akan jadi wacana? Bisakah ini dijadikan aset berupa kualitas individu yang mempunyai pribadi yang utuh, unggul, cerdas, sehat, toleran, peka, dan bijak melalui pembelajaran dan pencerapan terhadap musik? Akankah ini hanya akan berakhir sebagai harapan? Petanyaan-pertanyaan ini mungkin dapat kita jawab satu demi satu, melalui diri kita. Mulai dari apa yang bisa kita lakukan, dan mulai sekarang! 


\section{Daftar Pustaka}

Campbell, Don. 2001. Efek Mozart, Memanfaatkan Kekuatan Musik untuk Mempertajam Pikiran, Meningkatkan Kreativitas, dan Menyehatkan Tubuh. Jakarta: PT. Gramedia Pustaka Utama.

Dewantara, Ki Hadjar. 1962. Gunanya Wirama Didalam Pendidikan dan Hidup Manusia. Yogyakarta: Percetakan Taman Siswa.

Jamalus. 1989. Pembelajaran Musik melalui Pengalaman Musik. Houston: University of Houston.

Pekerti, Widia. 2002. Pendidikan Seni Musik Tari/Drama: Pusat Penerbitan Universitas Terbuka.

Soedarsono, R.M. 2003. Seni Pertunjukan, Dari Perspektif Politik, Sosial, dan Ekonomi. Yogyakarta: Gajah Mada University Press

Suhardjo, A.J. 2005. Pendidikan Seni Dari Konsep Hingga Program. Malang: Balai Kajian Seni dan Desain Universitas Negeri Malang.

Suharto, M. 2001. Kamus Musik. Jakarta: PT. Gramedia.

Suwito,DS. 1993. Teknik Termudah Menulis dan Membaca Not Balok.

Jakarta: CV. Titik Terang. 